\title{
The Aftermath of the Conflict on Fuel Subsidy Removal in Nigeria
}

\author{
B. E. A. Oghojafor ${ }^{1}$, F. C. Anyim² \& J. O. Ekwoaba ${ }^{2}$ \\ ${ }^{1}$ Department of Business Administration, Faculty of Business Administration, University of Lagos, Nigeria \\ ${ }^{2}$ Department of Industrial Relations and Personnel Management, Faculty of Business Administration, University \\ of Lagos, Nigeria \\ Correspondence: B. E. A. Oghojafor, Department of Business Administration, Faculty of Business \\ Administration, University of Lagos, Nigeria. E-mail: akpoyomareo@yahoo.co.uk
}

Received: September 24, 2013 Accepted: November 19, 2013 Online Published: February 28, 2014

doi:10.5539/jpl.v7n1p64 URL: http://dx.doi.org/10.5539/jpl.v7n1p64

\begin{abstract}
The removal of the subsidy on fuel by the Federal Government of Nigeria at the dawn of $1^{\text {st }}$ January, 2012 led to series of protests by the Labour Movement, Civil Society Groups Human Rights Activists and other Groups. The crisis eventually gravitated to a full blown strike which lasted for six consecutive days.

In this paper, attempt is made to examine the arguments raised by the protagonists and opponents of the fuel subsidy removal, the role played by the various stakeholders before and during the strike and the economic loss incurred by the country within the duration of the conflict. Furthermore, the paper takes a look at the bribery scandal and other events that followed the submission of the House of Representatives Ad hoc probe panel report on the oil subsidy regime.
\end{abstract}

A score board was drawn which shows a resultant win-win outcome by the parties. The paper concludes with recommendations that could avert reoccurrence of similar crisis in the future.

Keywords: economic and financial crimes commission, fuel subsidy, national industrial court, Nigeria labour congress, Nigeria national petroleum corporation, petroleum products pricing regulatory agency, subsidy re-investment empowerment programme, trade union congress

\section{Introduction}

On the eve of the 2012 New Year day, the Federal Government of Nigeria removed the subsidy on fuel thus increasing the pump price of a litre of fuel from $\$ 65$ to $\$ 141$. In some places at this period, fuel sells for as much as $\$ 250$ per litre as reported in some quarters (Punch, 2012).

From public opinion, the increase appears to be ill-timed as many people who travelled for the Christmas and New Year celebrations were caught in the crossfire; transport costs more than doubled and the poor masses and people on monthly salaries who were helpless did not find the "New Year" gift funny. The lifting of subsidy immediately shot fuel prices up as much as $225 \%$. It also sparked a price rise in food and transport costs across the country.

Government agents launched propaganda blitz to confuse the issue, lacing their presentations with exaggerated dividends of the expected savings. They also injected scare-mongering that the economy might be heading for collapse. They maintained the inevitability of deregulation of the downstream sector of the oil industry and buttressed their stand on the promise that fuel subsidy only benefits the rich in the society and that the windfall will be invested principally on infrastructure, job creation, health and agriculture. They cited for instance that the elite consumes more petroleum products than the masses who commute in public transport while the affluent have chains of vehicle and power their homes with generators that run on petroleum products. Furthermore, they contended that government resources used for subsidizing petroleum products will be freed to undertake the construction of good roads, clinics, hospitals, schools and provision of good drinking water.

Opponents of the fuel subsidy removal which includes the Trade Unions, Civil Society Coalition and Human Rights Groups noted that the government's safety net proposal in terms of the Subsidy Reinvestment and Empowerment Programme sounds laudable, however they observed that previous administrations had at one time or the other introduced similar palliatives that were rarely implemented. They argued that the government should have first met the yearnings of the public by implementing some of the key requests by labour unions in 
the first quarter of the year 2012 before withdrawing the subsidy on petrol. Furthermore, they noted that when President Goodluck Jonathan presented the draft of 2012 budget to the National Assembly, there was no mention of subsidy removal in his speech. Besides, they expressed fear that government's Subsidy Reinvestment and Empowerment Programme meant to mitigate the immediate impact of the subsidy removal on the populace may likely end up enriching a selected few (Punch, 2012).

In spite of the argument presented by both the proponents and opponents of the removal of the subsidy on petrol by the government, rallies were held across the country in protest of the subsidy removal by various groups: Labour Unions, Committee for the Defence of Human Rights; Civil Liberties Organisation; National Association of Nigerian Students; Social Democratic Movement amongst others. In several places angry protesters trooped to the streets, made bonfires on major roads, chanted anti government slogans and distributed leaflets calling for the rejection of the subsidy removal. In few instances, there were skirmishes between the protesters and the security agents deployed to disperse the protesters. Aside from the rallies, the Labour Unions on $4^{\text {th }}$ January 2012 gave the Federal Government ultimatum to reverse the pump price of petrol from $\$ 141$ to $\$ 65$ or face an indefinite nationwide strike billed to commence on $9^{\text {th }}$ January, 2012.

\section{Literature Review}

\subsection{Brief Theoretical Background of Conflict}

Conflict in some form and degree is part and parcel of virtually every facet of human life. Some people tend to view conflict as undesirable component of human life while others through history and experience have come to the conclusion that conflict can indeed lead to changes regarded as desirable in terms of generally acceptable human values. Conflict by every measure is an integral part of social existence, consequently the basic issue does not focus on suppression or avoidance of conflict but on how to manage it towards constructive and productive ends (Radin, 2007)

In Karl Marx's theory of class and class conflict, Marx and Engels (1932) state that in order to survive, humans must produce food and other material objects. The mode of production gives rise to two classes in society, the wealthy property owning class and the poor, weak propertyless class. In the scheme of things, the wealthier and more powerful class exploits the relationship between the classes and much of the wealth is appropriated in the form of profits by the property owners or capitalist whereas the wealth is produced by the labour power of the workers. Consequently, the wages paid to the workers are well below the value of the wealth they produce. Marx believes that the capitalist exploitation which has created a situation of distress and misery for the workers will give room to class consciousness. This scenario would in turn lead to agitation by workers against oppressive conditions of work and eventual downfall of the capitalist system which will be replaced with a socialist system and later communism.

Marx's theory of conflict relates to clashes of class interests which make the history of society a class struggle. However, some critics of Marx's work have raised a number of difficult questions on the theory. The first is, when and how would widespread class consciousness come about? Besides, transition from shop floor conflict to the wider political arena and the formation of association for the purpose of mass action is a process that rarely occurs. Furthermore, in the workplace, there is even conflict amongst the workers. Despite Marx's view on the overthrow and destruction of the capitalist system, the system has continued in the Western World for over two centuries since the dominant social class that owns and controls the means of production will largely monopolize political power and its position will be supported by law fashioned to protect and further their interests by state apparatus.

Simmel (1955) enriched the theoretical base of conflict theory by suggesting that conflict serves as a source of both integration and dissention. Intra-group conflict for example helps integrate society by serving as a safety valve for built up hostility; if workers are fighting one another, they will not organize and unify to challenge their employer.

Most writers agree that some conflict is both inevitable and necessary in effective organizations but a well-known psychologist, Maslow (1956) observes a high degree of ambivalence regarding the value of conflict. Maslow notes that managers intellectually appreciate the value of conflict and competition. They agree it is necessary ingredient of the free enterprise system. However, the actions of the managers demonstrate a personal preference for avoiding conflicts whenever possible.

According to Robbins (1974), it is not unnatural for an untrained or inexperienced person to avoid threatening situations and it is generally acknowledged that conflicts represent the most severe test of a manager's interpersonal skills. The tasks of the effective manager therefore is to maintain an optimal level of conflicts 
focused on productive purposes.

Hyman (1975) posits that conflict is an unavoidable evil in any modern organization, particularly in large ones. It is a product of industrialization. Work relations themselves are inevitable source of dispute. Iwuji (1987) describes disputes as a vital process towards seeming adjustments of expectations to economic realities.

\subsection{Characteristics and Nature of Conflict}

Albert (2000) notes that conflict pervades human existence. Not only are there always wars in one part of the globe or another, interpersonal conflict occurs in any human group and business organizations are certainly not an exception. He posits that if conflict is constructively managed, it can have positive outcomes. As Keenoy (1992) observes, business organizations in particular are fertile ground for conflict. The basic interest of employers and employees are opposed to each other and takes some effort and goodwill to reconcile them.

Batstone (1979) holds the view that conflict refers to an opposition of interest or perspective and generally involves corresponding forms of action. In the view of Otobo (1987) conflict may be organized or unorganized. Organized conflict has to do with a conscious strategy designed to change the situation identified as the source of conflict. In unorganized conflict, the workers react spontaneously to the situation in the only way open to them as individuals, it could be through outright sabotage or indiscipline. In general, where workers experience sufficiently acute deprivations, unrest will be expressed in one form or the other. The circumstance of the case will however, influence what form the expression of the conflict will take. It has been argued that the examination of conflict should be expanded to include the total range of behaviour and attitude that express opposition and divergent orientations between individuals owner and managers on one hand and the working people and their organization on the other (Deutsch, 1962).

The approach adopted in managing conflict is a function of the ideology or frame of reference held by the parties in conflict (Poole, 2001). The ideology held by the parties has the tendency to either ameliorate or exacerbate conflict situation between parties. In a conflict situation, there are different interest who are likely to prosper or suffer together as an aftermath of conflict (Grover, 2008).

Conflict can be destructive when left to tear all the stakeholders involved apart due to poor or improper management, consequently, conflict becomes dysfunctional and should be checked (Onyishi \& Asogwa, 2009). Conflict can be defined in terms of interest, values and psychological disposition of the actors. In most cases, conflict is a mixture of the three concepts and in some instance can vary (Chanlat, 2001). Conflict in overt form requires immediate handling to minimize its gravitating to a dysfunctional level (Robbins \& Judge, 2008).

White-collar workers (office staff) have been identified with organized conflict, while the blue-collar workers (technicians) with both organized and unorganized conflict. Workers in higher skilled occupations who form more cohesive work groups and possess greater bargaining strength are more likely to both pursue grievance(s) through the formal negotiating procedure rather than to engage in strikes, go slows and overtime bans. Lower skilled groups, who figure least prominently in such collective activities, have the highest level of involvement in the measurable forms of unorganized conflict (Deutsch, 1973).

Some conflicts may have serious economic repercussions while others do not have any significant effect on the economy. In similar vein, conflict organized during recession or depression in the economy will have no appreciable impact on the economy or organization. In reality the number of conflicts fluctuates with the movement of the business cycle. From empirical findings, number of conflicts decline during depression when organizations are presumed to be relatively strong and vice versa (Anyim, 1984).

According to Smith (2002) and Lee (2011), there is a traditional belief that conflict is destructive, and its impact is always negative as it usually leads to gradual loss of performance, consequently, conflict should be avoided. However, when conflict is avoided, it may lead to violence, destruction and irrationality. The response a conflict will elicit determines whether the outcome or aftermath will be positive or negative (Khanaki \& Hassanzadeh, 2010).

Conflicts have considerable value when they are managed constructively. The issue is not whether conflicts occur, but rather how they are managed and resolved. Desirable outcome of constructively managed conflict includes greater quantity and quality of achievement, complex reasoning and creative problem solving; higher quality of decision making; being able to deal with stress and cope with unforeseen adversities; increase motivation and energy to take action; greater sense of caring, commitment, joint identity and cohesiveness with an emphasis on increased liking, respect; and increased incentive to change (Deutsch, 1973; Johnson, 1970; Johnson \& Johnson, 1994; Johnson \& Johnson, 1995). 
Socio - economic reforms have been a fertile ground for crisis worldwide. Reactions that follow reforms appear in various forms: international coercion, normative emulation and competitive mimicry. Basically, the essence of reforms is geared towards reshaping the role the state play in the economy. (Henisz, Zelner \& Guillen, 2005).

USAID (2005):

holds the view that Nigerian government's capacities for managing conflicts appears weak as it has not explore other available strategies for conflict management.

In the light of the gap, the government usually resorts to using Nigerian mobile policemen who are not trained and unable to manage conflict effectively. The alternative is to bring in military to scene of violence with order to "Shoot on Sight". This trend gravely breeds serious violation of human rights and heightening of violence (Ibeanu). In a democratic setting, conflict is never eliminated but could be better regulated. Conflict is accepted as an inevitable consequence of a complex society predicated on a complex culture. The number of conflicts and the issues involved will differ in historical periods as well as the techniques for carrying them out. Like other institutional frameworks, it need be emphasized that conflict is not static but a phenomenon passing through an evolutionary process (Anyim, 2009).

\subsection{The Intervention of National Industrial Court (NIC) in the Dispute}

Having failed to persuade the labour leaders to shelve the planned strike, on $6^{\text {th }}$ January, 2012, Federal Government went to National Industrial Court and made a passionate appeal through the Office of the Attorney General of the Federation (AGF) to restrain the Nigeria Labour Congress (NLC) and Trade Union Congress (TUC) from embarking on a strike action or conduct mass rallies and street protest across the country pending the determination of a motion on notice that was filed before it by the Federal Government. Consequently, the National Industrial Court issued an ex-parte order restraining, the Nigeria Labour Congress (NLC) and Trade Union Congress (TUC) from embarking on the action in the interest of peace, national security and stability of the country.

The labour leaders in response termed the National Industrial Court's order as a "black market" injunction, reassuring workers and other Nigerians that the strike scheduled to commence on $9^{\text {th }}$ January, 2012 would go on as planned. The labour leaders based their posture or position on the premise that they were neither aware of such order nor served.

\subsection{The Role of the Legislature in the Dispute}

Following the spontaneous protests that greeted the removal of the subsidy on fuel across the country, the House of Representatives which had earlier scheduled to resume on the $10^{\text {th }}$ January, 2012 had to cut short its recess by two days to attend to the national challenge and emergency.

On the $8^{\text {th }}$ of January, 2012, members of the House of Representatives held extra-ordinary emergency meeting and asked the executive arm of government to suspend the removal of subsidy on petroleum products in appreciation of the mood of the nation and to allow for consultations between the various stakeholders. The House also implored the labour unions and other interest groups to suspend the strike slated to commence on $9^{\text {th }}$ January, 2012 and submit to further dialogue while appealing to Nigerians in general to exercise restraint in expressing their displeasure over the removal of the fuel subsidy.

The House went further to invite the representatives of the executive arm of government including the Secretary to the Government of the Federation and the labour leaders to meet with the Ad-hoc Committee of the House set up to interface with the Representatives of the two parties in dispute. The purpose of the meeting was to find a common ground to narrow their differences and avert the strike. Other decisions taken by the House were setting up two ad-hoc committees; one to mediate between the executive and the labour leaders and the other to verify and determine the actual subsidy requirements for the country and also to monitor the subsidy regime.

\subsection{Commencement and End of the Strike}

Irrespective of the intervention of the House of Representatives, the organized labour and the Civil Society Groups started the strike on $9^{\text {th }}$ January, 2012 to force government to reverse its decision on the removal of fuel subsidy. The strike which lasted for five days appears to be hugely successful. Most offices and shops were under lock and key and the more daring citizens took to the streets to protest openly. In the course of the protest, few persons were killed by the Nigerian Police.

In-between the period in which the strike lasted, the Senate President, Senator David Mark and some of the Senators held series of meeting with the labour leaders and government representatives all in a bid to end the crisis. On $16^{\text {th }}$ January, 2012, President Jonathan Goodluck made a nationwide broadcast that the price of fuel 
has been reduced from $\$ 141$ to $\$ 97$. He assured the Nigerian people that government recurrent expenditure would be slashed, more transparency would be ensured in oil regime and a more rigorous anti-corruption crusade would be pursued by government. The Nigeria Labour Congress and Trade Union Congress after due consultations with its various stakeholders suspended the strike on $16^{\text {th }}$ January, 2012.

On $16^{\text {th }}$ January, 2012, the National Industrial Court (NIC) ordered the Federal Government, Nigeria Labour Congress (NLC) and Trade Union Congress (TUC) to resolve their dispute and report back with the terms of settlement on $10^{\text {th }}$ February, 2012. The President of the Court gave the order at the resumed hearing in the suit filed earlier by the government on $6^{\text {th }}$ January, 2012. However, the Nigeria Labour Congress and the Trade Union Congress who were the respondents did not appear in court, even though the strike was suspended on $16^{\text {th }}$ January, 2012.

The National Industrial Court President cited Section 20 of the National Industrial Court ( $3^{\text {rd }}$ alteration Act, 2011) as stating that in any proceedings in the court, the court may promote reconciliation amongst the parties hereto and encourage and facilitate the amicable settlement thereof. The Court President stated that the court had taken judicial notice of the meetings between organized labour and government as well as the steps that had been taken so far. The President added that it is the duty of the court to make order as to promote reconciliation and encourage amicable settlement of the disputes in the interests of justice.

\subsection{Appraisal of the Costs of Fuel Subsidy Crisis to the Economy}

A country's Gross Domestic Product (GDP) is a measure of economic activity and shows the productive capacity of all sectors of the economy. As an aftermath of the fuel subsidy crisis, it is not unexpected that the country's GDP growth rate for year 2012 would be adversely affected in all sectors of the economy. Table 1 shows the GDP growth rate in Nigeria from 2005 to 2009 measured at 1990 constant basic prices.

Table 1. GDP growth rate $(2005-2009)$

\begin{tabular}{lllllll}
\hline & SECTOR & $\mathbf{2 0 0 5}$ & $\mathbf{2 0 0 6}$ & $\mathbf{2 0 0 7}$ & $\mathbf{2 0 0 8}$ & $\mathbf{2 0 0 9}$ \\
\hline 1. & Agriculture & 7.06 & 7.40 & 7.19 & 6.54 & 5.94 \\
2. & Industry & 1.71 & -2.51 & -2.23 & -2.18 & 0.62 \\
3. & Building \& Construction & 12.10 & 12.99 & 13.03 & 13.06 & 12.26 \\
4. & Wholesales \& Retail & 13.51 & 15.26 & 15.20 & 14.00 & 11.27 \\
5. & Services & 7.96 & 9.18 & 9.88 & 10.45 & 10.88 \\
& TOTAL (GDP) & 6.51 & 6.03 & 6.45 & 5.98 & 6.66 \\
& NON-OIL (GDP) & 6.80 & 8.09 & 8.96 & 9.40 & 8.33 \\
\hline
\end{tabular}

Source: National Bureau of Statistics/CBN Statistical Bulletin (Various Years).

With the return of democracy in Nigeria in 1999, the quest of successive governments through their various reform programmes is to achieve $10 \%$ aggregate growth rate in GDP in order to promote economic transformation and place the country in the path of prosperity. However, from the data presented in the table, achieving the targeted aggregate growth rate of $10 \%$ seems to be an illusion or mirage.

In terms of the costs of fuel subsidy crisis to the economy, many figures were presented by various interests but the National Bureau of Statistics which is a government agency states that the economy lost an estimated $\$ 207.4$ billion during the strike. According to the Bureau, the biggest losses were incurred in the retail and the oil and gas sector at $42 \%$ and $14 \%$ respectively of the total loss in output during the period.

The Nigeria Finance Minister, Dr. Ngozi Okonjo- Iweala put the loss at $\$ 300$ billion based on the Nation’s Gross Domestic Product (GDP) while the Central Bank of Nigeria stated that up to $\$ 100$ billion was lost daily while the strike lasted.

Irrespective of the inability of the country's GDP to meet the targeted aggregate growth rate, the fuel subsidy crisis no doubt has added additional strain and exacerbated the economic problem of the country.

Aside from the figures presented by the foregoing institutions, and in specific terms, it should be noteworthy that at the seaport where the strike was total, especially at the nation's largest port; Apapa Port Complex and Tin Can Island, Lagos amongst others, every cargo-laden vessel incurred demurrage for everyday of the stoppage of 
operations. Many importers face distress and had to transfer the additional cost to consumers in the form of higher prices. The direct effect of the strike triggered an inflationary spiral that was hurtful to citizen, businesses and ultimately the national economy.

Taking a glance at the service industry, Banks and Insurance companies were equally affected as they were closed to transaction, just as the aviation sector grounded to a halt. Financial institutions like several other corporate entities might at the end of their financial year miss their performance and profit targets or projections. It is also more worrisome as the corporate bodies cannot shirk their responsibility in paying employees' emolument despite the fact that no productive work was done during the period of the strike.

At the Murtala Mohammed International Airport, Lagos and Nnamdi Azikiwe International Airport, Abuja the sight of hundreds of stranded air passengers buttressed the fact that at foreign airports, larger numbers of air travelers would have been unable to fly to Nigeria for sundry business. Many whose planned visits to Nigeria were connected with business investment and allied transactions were compelled to abandon such projects. In similar vein, some amongst those stranded were supposed to resume work or be at their duty post. For being absent from work especially those on essential services might lead to their losing their jobs.

In the course of the strike, the threat of stoppage of oil exploration and production operation as well as crude oil lifting and export at the terminals by the senior oil workers. (Petroleum and National Gas Senior Staff Association - PENGASSAN) would have been catastrophic for the nation if the union had carried out the threat.

The oil and gas and the ports ranked as the government's first and second biggest sources of revenue respectively. Unfortunately, for these sectors the crisis created strike- induced economic losses that could have assisted in counteracting the government's projected gains from the additional revenue from the higher petrol price. Consequently, the scenario created room for the new pump price of $\$ 97$ to be wrestling with inflationary trends.

2.7 The Trends in Fuel Pump Price Increases from 2000 to 2012

Under ex-President Obasanjo's regime, the nation witnessed seven successive increases from year 2000 to 2007 and under President Goodluck Jonathan, once in 2012 as presented in table 1.

Table 2. Fuel price increases (2000 to 2012)

\begin{tabular}{|c|c|c|c|c|c|}
\hline Date & Cause of Strike & Duration & Resolution & $\begin{array}{l}\text { Difference } \\
\text { (N) }\end{array}$ & $\begin{array}{c}\text { Difference } \\
(\%)\end{array}$ \\
\hline June 1, 2000 & $\begin{array}{c}\text { Price of petrol increased to } \\
\quad \$ 30 / \text { litre from } \$ 11\end{array}$ & Eight days & $\begin{array}{l}\text { Price reduced to } \\
\quad 20 \text { per litre }\end{array}$ & 9 & 81 \\
\hline June 16, 2002 & $\begin{array}{l}\text { Price increased from } \\
\$ 20 / \text { litre to } \$ 26 / \text { litre }\end{array}$ & Two days & $\begin{array}{l}\text { Price retained at } \\
\quad 26 \text { per litre }\end{array}$ & 6 & - \\
\hline $\begin{array}{c}\text { June } 30-\text { July } \\
8,2002\end{array}$ & $\begin{array}{l}\text { Price increased for } \\
\$ 26 / \text { litre to } \$ 40 / \text { litre }\end{array}$ & Eight days & $\begin{array}{l}\text { Price reduced to } \\
\$ 34 \text { per litre }\end{array}$ & 8 & 39 \\
\hline June 9, 2004 & $\begin{array}{l}\text { Price increased from } \\
\$ 34 / \text { litre to } \$ 50 / \text { litre }\end{array}$ & Three days & $\begin{array}{l}\text { Government and } \\
\text { NLC agreed to a } \\
\text { new price of } 42 \\
\text { per litre }\end{array}$ & 8 & 24 \\
\hline $\begin{array}{l}\text { October 11, } \\
2004\end{array}$ & $\begin{array}{l}\text { Price increased from } \\
\$ 42 / \text { litre to } \$ 52 / \text { litre }\end{array}$ & Three days & $\begin{array}{l}\text { Government } \\
\text { appointed the } 19 \\
\text { member Senator } \\
\text { Ibrahim Mantu } \\
\text { Committee on } \\
\text { palliatives. }\end{array}$ & 10 & 24 \\
\hline $\begin{array}{l}\text { September } \\
2005\end{array}$ & $\begin{array}{l}\text { Price increased from } \\
\$ 52 / \text { litre to } \$ 65 / \text { litre }\end{array}$ & No strike & $\begin{array}{l}\text { Protested by NLC } \\
\text { and Civil Society } \\
\text { Groups led to a cut } \\
\text { in price. }\end{array}$ & 13 & 25 \\
\hline June 20, 2007 & $\begin{array}{c}\text { Price increased from } ¥ 65 \\
\text { to } \$ 70 / \text { litre }\end{array}$ & Four days & $\begin{array}{l}\text { Price reduced to } \\
\# 65 \text { per litre }\end{array}$ & - & - \\
\hline
\end{tabular}




\begin{tabular}{|c|c|c|c|c|c|}
\hline January 1, 2012 & $\begin{array}{l}\text { Price increased from } \$ 65 \\
\text { per litre to } \$ 141 \text { per litre }\end{array}$ & Five days & $\begin{array}{c}\text { Price reduced to } \\
\quad \$ 97 / \text { litre }\end{array}$ & 32 & 49 \\
\hline
\end{tabular}

Source: Authors (2012)

From the data presented on table 1, fuel price increases during the regime of Obasanjo (2000 to 2007) ranged between $¥ 6$ to $\$ 13$ and during Jonathan's regime between $\$ 13$ to $\$ 32$ which represents $146 \%$ increase.

Considering the leap in pump price of fuel, the people are not against deregulation in the downstream sector of the petroleum industry as they have seen the benefits of deregulation in the Telecom sector nor are they against the government's effort at fiscal restructuring or closing the drain pipe on the resources of the nation. They seem to be against the government doing so purely at their expense. As one columnist puts it "what is happening presently is not deregulation but an all-time high fuel pump increase unprecedented in the history of our nation by government that has gone broke due to excessive and reckless spending largely on themselves (Bakare, 2012). Besides, the people wondered why only a few months ago the government spent huge sums of money on campaign, ordered additional jets for the Presidential fleet coupled with elected and appointed office holders living in affluence while some of the government policies including hike in fuel price are stifling life out of the poor masses. For instance, consider the fate of the barbers, hair dressers, business centres, pepper grinders, welders, restaurant operators, etc whose livelihood depends on fuel powered machines because there is no regular public electricity. Consider the impact of astronomic fuel pump price in the cost of their most vital factor of production and by how much do they raise prices to cover costs without inflicting serious injury on the final consumers.

In analyzing the trend further, petrol pump price per litre in relation to the minimum wage of Oil Producing and Exporting Countries (OPEC) was examined considering the fact that Nigeria is currently the largest oil producer in Sub-Saharan Africa and the sixth largest producer in the world, averaging 2.7 million barrels per day (bbl/d) in 2010. Table 2 below shows the trend:

Table 3. Petrol pump price per litre in comparison to minimum wage in OPEC countries

\begin{tabular}{lcc}
\hline OPEC Member & PMS Price/Litre & Minimum Wage \\
\hline Venezuela & $\$ 3.61$ & $\$ 16,839$ \\
Kuwait & $\$ 34.54$ & $\$ 99,237$ \\
Saudi Arabia & $\$ 25.12$ & $\$ 86,585$ \\
Iran & 102.05 & $\$ 101,250$ \\
Qatar & $\$ 34.54$ & $\$ 217,362$ \\
UAE & $\$ 78.18$ & $\$ 55,957$ \\
Algerian & $\$ 63.69$ & $\$ 23,813$ \\
Libya & $\$ 26.69$ & $\$ 25,813$ \\
Iraq & $\$ 59.66$ & $\$ 18,900$ \\
Nigeria & $\$ 97$ & \\
\hline
\end{tabular}

Source: Adapted from Compilation of Group 2 (IRP 811) MILR 2010 Class.

From the table, Nigeria has the lowest minimum wage i.e. 18,900 in comparison to other OPEC countries, the highest being the United Arab Emirate (UAE) with $\$ 217,362$. On pump price of petrol, Iran has the highest ( 102) with a minimum wage of $\$ 86,585$ but in relation to Nigeria, the current pump price of petrol is $\$ 97$ with a minimum wage of $\$ 18,900$. In comparative terms, the people of Iran and other OPEC countries are still better than the people of Nigeria bearing in mind that they have a higher minimum wage $(\$ 86,585)$ while Nigerians have $\$ 18,900$ to purchase a litre of fuel at $\$ 97$.

The foregoing attests to why the people embarked on mass protests to force government to reverse the trend. One positive and crucial lesson that emanated crisis is that Nigerians were united beyond class, ethnic, regional and religious line in this struggle to fight for their common rights. 


\subsection{The Score Board of the Fuel Subsidy Removal Conflict}

Despite the fact that the country produces barrels of crude oil annually, the government is still forced to import almost $70 \%$ of its fuel supply because of inadequate and run down refineries. Furthermore, it is abnormal for a country of 160 million people to depend on only three refineries not functional for retail consumption.

A cursory look at the fuel pump price increase between year 200 to 2007 by Obasanjo's regime ranged from $81 \%$ to $24 \%$ but if the price increase for year 2000 is played down or discounted i.e. from $\$ 11$ to $\$ 20$ because that is the first pump price increase by the regime, the increase at subsequent years i.e. year 2002 to 2007 ranged from $39 \%$ to $24 \%$. President Jonathan's administration before the crisis hiked the fuel pump price from $\$ 65$ to $\$ 141$ which represents $116 \%$ increase but the emergent crisis forced the government to reduce the price from $\$ 141$ to \# 97 which represents $49 \%$ increase.

In comparative terms, the Jonathan's administration increased the fuel pump price by $49 \%$ i.e. from $\$ 65$ to $\$ 97$ irrespective of the depressive state of the economy whereas the highest percentage increase by the Obasanjo's regime was $39 \%$ increase. From the foregoing analyses, the government seems to have strategically succeeded in its bid to cut down subsidy on fuel pump price. Besides, it is not unlikely that if the Jonathan's administration had adopted the piecemeal approach to fuel pump price hike by past regimes, it would not have achieved the current astronomical increase.

On the part of NLC, TUC, Civil Society Groups, religious leaders and the ordinary citizens or Nigerians, it is truism that the government did not restore the pump price of petrol to $\$ 65$ as demanded by Nigerians, the attendant strike and protests against the removal of the subsidy however, recorded some gains. For instance, the Economic and Financial Crimes Commission (EFCC) beamed its search light on the books of the Petroleum Products Pricing and Regulatory Agency (PPPRA). The Minister of Petroleum Resources was compelled to send a plea across to the National Assembly to pass the Petroleum Industry Bill (PIB) that has been lingering for a long period. There was a lot of startling revelations by invited stakeholders at the sitting of the House of Representatives Ad-hoc Committee on the monitoring of the subsidy regime amongst others. However, in battles, no one party can win $100 \%$ hence the paradigm of win-win approach underscores the outcome of this conflict.

\subsection{Fuel Subsidy Report and \$620,000 Bribery Scandal}

Sequel to the six day mass protest across the country, part of the measures that placated angry Nigerians was the move by the government to probe the oil subsidy scam by the House of Representatives Ad-hoc Committee on the management of fuel subsidy. The investigation report which was submitted on $17^{\text {th }}$ April, 2012 shed light on the dealings in the oil and gas industry following claims that the country was losing huge sums of money because of the fuel subsidy regime.

The report amongst others uncovered staggering sum of $\$ 2.58$ trillion, an amount in excess of $50 \%$ of Nigeria's 2012 national budget of N4.4 trillion was expended on a budgetary item that should have cost 240 billion. The report also revealed that about $\$ 1.7$ trillion out of the $\$ 2.58$ trillion could not be properly accounted for consequently, it should be returned to the coffers of government by alleged defaulters which include government agencies and oil marketers. The report identified the agencies as a the Nigerian National Petroleum Corporation (NNPC) and the Petroleum Products Pricing Regulatory Agency (PPPRA) and 72 oil marketing firms as authorizing and receiving illegal payments respectively. According to the report, NNPC is to refund $\$ 310.4$ billion it fraudulently claimed and another $\$ 285$ billion for fuel imports above PPPRA level. It is also to refund another $\$ 108.6$ billion the corporation paid itself. 18 firms which failed to honour the House panel summons were asked to refund $\$ 41.9$ billion as it is believed that these firms deliberately refused to appear because they have something to hide.

The House of Representatives in May, 2012 forwarded copies of the report to President Goodluck Jonathan, Attorney General of the Federation (AGF) and Minister of Justice, Chairman of Economic, Financial and Crime Commission (EFCC) requesting for executive action against the companies indicted and the loot recovered within three months.

However, the House of Representatives probe report assumed a dramatic twist in June, 2012 when oil magnet, Mr. Femi Otedola alleged a $\$ 3$ million bribery deal between himself and Farouk Lawan, Probe Panel Chairman in which he had given Lawan a sum of $\$ 620,000$ as part payment but refused to pay the balance because the lawmaker forced him into the deal. Furthermore, Otedola disclosed that the deal was made in order to remove the name of his firm, Zenon Oil and Gas Ltd from the list of firms indicted in the oil probe. A video showing the payment was said to have been shown to some members of the National Assembly as proof that such transaction did take place. Mr. Boniface Emenaho who acted as clerk to the panel was also mentioned to be part of the deal 
by Otedola.

Lawan admitted collecting the money but claimed it was not a bribe but as an evidence that Otedola has tried to influence him unduly. The scandal came under Police investigation in which no conclusion has been reached as at the time of this presentation following non-recovery of the $\$ 620,000$.

The House of Representatives reacting to the scandal mandated its Committee on Ethics and Privileges to investigate the matter. The Committee quizzed the seven members of the probe panel aside from its Chairman and Secretary. All the members denied knowledge of the transaction between Lawan and Otedola. The House Committee invited Otedola to their sitting in camera but Otedola declined to testify in camera insisting that he would only talk in the open and the full glare of the media. The Committee rejected his condition that he could not dictate on how it should run its affairs. The House however, maintained that it was only interested in the conduct of its members whose attitude was called to question and since Otedola made the allegation he could assist the Committee in making its members to face punishment for the alleged bribery scandal. It added that it was the responsibility of the security agencies to deal with Lawan and Otedola at another level and not the Committee. From the foregoing, the interventionist role by the House of Representatives was also inconclusive.

President Goodluck Jonathan speaking through his Special Adviser on Media and Publicity, Dr. Reuben Abati on the report of the Management of the Fuel Subsidy assured Nigerians that he would act in the best interest of Nigerians. Having received the House of Representatives probe report, the Federal Ministry of Finance set up a Technical Committee made up of experts to scrutinize the fuel subsidy payments to marketers during the 2011 financial year. The Committee's report was criticized in some quarters for not giving oil marketers the opportunity to defend themselves. Consequently, President Goodluck Jonathan set up a Presidential Committee headed by Mr. Aigboje Aig-Imoukhuede, Managing Director of Access Bank Plc who also earlier headed the Technical Committee to verify and reconcile the findings of the Technical Committee. From the findings of the two Committees, some of the companies that were earlier cleared by the House of Representatives Ad-hoc probe panel were indicted. This revelation heightened suspicions that the House Committee might not have done a thorough work and probably might have allowed some of the culprits or offenders to influence the outcome of its investigation.

In a bid to reform and sanitize the Petroleum industry, President Goodluck Jonathan set up three Committees in February, 2012. The first Committee was Petroleum Revenue Special Taskforce headed by Mallam Nuhu Ribadu to determine and verify all Petroleum upstream and downstream revenue (royalties and taxes etc) due to Federal Government and other transactions between 2002 to 2012. The Second Committee headed by Mr. Dotun Sulaimon was to design a new corporate governance code for ensuring full transparency, good governance and global best practices in the NNPC and other parastatals in the oil and gas industry. The third Committee headed by Dr. Kalu Idika Kalu was charged with the responsibility of conducting a high level assessment of the nation's refineries and recommend ways of improving their efficiency and commercial viability. The three Committees submitted their reports to the Federal Government on $2^{\text {nd }}$ November, 2012 and it is hoped that the recommendations made by the committees would be considered and flawlessly implemented by the government.

In line with the outcome of the probe, the EFCC have arraigned suspects that defrauded the nation under the Federal Government's Petroleum support fund. The charges preferred against the accused border on conspiracy, obtaining money by false pretences, forgery and use of false documents to obtain various sums of money from government. The EFCC investigation has been on going and it is expected that more suspects in the oil and gas deal would be put on court trial or arraigned periodically as investigation progresses. The government must rise to the challenge and muster enough political and moral will to bring to justice all those involved in the oil subsidy heist to serve as a deterrence to others.

\section{Conclusion}

The challenges in the oil industry do not lie within the industry operators alone but must be gleamed from macro perspective and given a comprehensive attention by the state. The adoption of ad-hoc piecemeal economic policy and experimentation tend to unleash hardship and suffering on the masses.

In the course of the crisis, Nigeria lost properties both in human and economic dimensions and its reputation within the international community is likely to have been affected negatively within the period. Conflict is not necessary a bad phenomenon but an engine for social change and progress. Conflict may point up weaknesses in the econo-socio-political structures and could as well reveal exploitative situations or selfish motives nevertheless conflict becomes a destructive weapon when the button is wrongly pressed. On such occasions, the disputants are left to groan over the consequences and the inconveniences would be suffered by other helpless 
parties.

In the light of the foregoing, government will do well to evolve visionary leadership anchored on transparency, imbibe the culture of reducing waste in the system and also ensuring that the wealth from our common resource (oil) is not carted away by some corrupt individuals in our midst otherwise the creditability of government will be put to test.

Nigerians scored a major point by rising courageously as people to take their destiny in their hand in the six days crisis which consequently compelled government to reduce the fuel pump price from $\$ 141$ to $\$ 97$. The issue of fuel subsidy withdrawal protests, riots and loss of lives must be a history for posterity and should not be allowed to rear its ugly head. In this respect, government must provide the infrastructures it had promised the people through its Subsidy Re-Investment Empowerment Programme (SURE), otherwise Nigerian would henceforth hold its leaders accountable for the woes of the country.

Recalling how the crisis started in the New Year day, Nigerians used the excuse of the fuel subsidy removal to vent their pent-up anger and frustrations over the horrendous management of the nation's petroleum resources. Furthermore, the catalogue of events that followed the revolt would linger in the minds of Nigerians for a long time. However, the bribery scandal cautiously should not undermine the subsidy probe reports that unveiled monumental and mind-boggling revelations. The personalities involved in the bribery scandal if found sufficiently culpable should be tried by appropriate court of justice. Conclusively, the oil subsidy probe report must be implemented to the letters and not buried like similar reports in the past.

\section{Policy Recommendations}

The street protests and strike which greeted the removal of subsidy on petrol by the Federal Government glaringly caused some dislocations to the economy while some citizens lost their lives in the process. However, the disputants or parties to the dispute must have learnt some bitter lessons from the episode. On the strength of the foregoing and to guard against future reoccurrence of conflict of this magnitude, it is hereby recommended as follows:

i. On critical and sensitive issues of this nature, government should make it a point of duty to have a wider consultation with various stakeholders rather than embarking on a unilateral action. This does not translate to questioning the sovereign power of the state but it is based absolutely on the premise that the process of governance is a social contract which requires mutual agreement between the government and the governed.

ii. There is need to clean up the existing domestic refineries and making them functional in order to mitigate the heavy reliance on fuel importation.

iii. There is need to provide enabling environment for private investors and companies to establish refineries in Nigeria. This will no doubt augur well for the economy as the more refineries, the better for competitive outcomes under a deregulated regime. Findings have shown that a good number of companies have been issued with license to establish refineries in Nigeria but have been reluctant to do so because of perceived uncertainties and disenabling environment in the petroleum industry.

iv. Paradoxically, government may have strong arguments to support its policy change on fuel subsidy, but it must ensure that its promises are delivered to the people through its vehicle of "Subsidy Re-Investment Empowerment Programme" (SURE) in order for it to regain its credibility judging from the unfulfilled expectations by past regimes on same issue.

v. The Presidential directive that the basic salaries of top government functionaries be slashed by $25 \%$ and also curtailing frivolous tours, attendance of foreign courses and trips should be strictly adhered to. Though the $25 \%$ reduction in pay can be likened to a cup of water out of an ocean.

vi. The National Assembly as a matter of urgency should pass the Petroleum Industry Bill (PIB) into law to guide the regulators and investors to be alive to their responsibilities and also to promote the growth and development of the industry.

vii. The government should device accurate statistical mechanism in arriving at the exact amount of fuel subsidy expended annually rather than allowing relevant government agencies issuing conflicting figures which is very embarrassing to the country. For instance, Central Bank of Nigeria (CBN), Petroleum Products Pricing and Regulatory Agency (PPPRA) and the Federal Ministry of Finance paraded conflicting figures before the House of Representatives Ad-Hoc Committee probing the fuel subsidy regime. 
viii. Government should exhibit the political will to block all the loopholes and conduits used by some highly placed individuals or "cabals" in the society to loot the funds meant for fuel subsidy not minding whose ox is gored. If the perpetrators of these corrupt practices which have bedeviled the management of fuel subsidy are purged, a large amount of money would have been saved and channeled to other areas of needs that would be beneficial to the masses.

ix. Due to the current consumption level, it has become imperative for government to import fuel to augment domestic supply. However, there is need for government to rationalize the petroleum products importers which includes politicians, their associates, cronies and jobbers and those who have no business with the industry rather the importation should be restricted to reputable oil marketing companies and the Nigeria National Petroleum Corporation (NNPC) as was the case many years ago. By this means, government can find it easier to monitor the activities in this sector effectively and ensure accountability.

x. The Labour Movement refused to appear before the country's apex court on labour matters, National Industrial Court (NIC) on the guise of not being aware of the court's order and its earlier insistence that government must revert to $¥ 65$ before it can hold talks on fuel pump price hike with government negate the ethics of good labour and industrial relations practice. Labour should play the game according to set rules and to bear in mind that the essence of effective collective bargaining is to arrive at a win-win solution mutually acceptable to the parties.

xi. The reports of the Ad-hoc Committee of the House of Representatives that probed the fuel subsidy regime and the probe by the Economic and Financial Crimes Commission (EFCC) of all financial transactions relating to payments of subsidy on fuel in the offices of the Petroleum Products Pricing and Regulatory Agency (PPPRA) should be made public by the government and not swept under the carpet going by past experience on reports of similar probes. Persons and government officials found culpable should be brought to book. Akin to this, the outcome of the deliberations between government team and labour at the Belgore Committee set up at the instance of the government should also be implemented to the letters when the report is submitted to the government.

\section{References}

African News Service online. (2012, February 6). Retrieved from http://allafrica.com/nigeria

African News Service online. (2012, May 11). Retrieved from http://allafrica.com/nigeria

Albert, I. O. (2000). A Framework for Conflict Mapping, Tracking and Analysis. Ife Psychologia, 8(2). http://dx.doi.org/10.4314/ifep.v8i2.23582

Anyim, et al. (2012). Trade Dispute and Settlement Mechanism in Nigeria: A Critical Analysis. Interdisciplinary Journal of Research in Business, 2(2), 1-8.

Anyim, F. C. (1984). The Management of Trade Disputes in Nigeria During the First Military Regime (1966-1979). Unpublished CIPM Thesis.

Anyim, F. C. (2009). A Critique of Disputes Settlement Mechanism in Nigeria: 1968 to 2004. Unpublished Ph.D Thesis, University of Lagos, Nigeria.

Batstone, E. (1979). In G. M. Stephenson, \& C. J. Erptherton (Eds.), The Organization of Conflict from Industrial Relations: A Social Psychology Approach. John Wiley and sons, London.

Brand Headlines online News. (2013, July 28). Retrieved from http://brandcrunch.com.ng

Compass News online. (2013, May 7). Retrieved from http://www.nigeriancompass/nigeria-compass-newspaper

Deutsch, M. (1962). Co-operation and Trust: Some Theoretical Notes. In M. R. Jones (Ed.), Symposium on Motivation. Lincoln, University of Nebraska Press.

Deutsch, M. (1973). The Resolution of Conflict. New Haven, Yale University Press.

Henisz, W. J., Zelner, B. A., \& Guillen, M. F. (2005). The Worldwide Diffusion of Market-Oriented Infrastructure Reform, 1977-1999. American Sociological Review, 70(6). http://dx.doi.org/10.4314/ifep.v8i2.23582

Hyman, R. (1975). Industrial Relations: A Marxist Introduction. London, Macmillan.

Ibeanu, O. (2006). Civil Society and Conflict Management in the Niger Delta: Scoping Gaps for Policy and Advocacy. Lagos, CLEEN Foundation.

Iwuju, E. C. (1987). Settlement of Trade Disputes. In D. Otobo, \& M. Omole (Eds.), Readings in Industrial 
Relations in Nigeria. Lagos, Malthouse Publishing.

Johnson D. W., \& Johnson, F. (1994). Joining Together: Group Theory and Group Skills (5th ed.). Boston: MA Allyn and Bacom.

Johnson, D. W. (1970). Social Psychology of Education. Edina MN International Book Company.

Johnson, D. W., \& Johnson, R. T. (1995), Teaching Students to be Peace Makers (3rd ed.). MN International Book Company.

Keenoy, T. (1992). Constructing Control. In J. F. Harttey, \& G. M. Stephenson (Eds.), Employment Relations: The Psychology of Influence and Control at Work. Oxford: Blackwell.

Khanki, H., \& Hassanzadeh, N. (2010). Conflict Management Styles: The Iranian General Prefernce Compared to Swedish. International Journal of Innovation, Management and Technology, 1(4).

Kogi Report Online News. (2012, October 4). Retrieved from http:/www.kogireports.com/tag/grace-fm

Lee, K. L. (2011). An Examination Between the Relationships of Conflict Management Style and Employees' Satisfaction. International Journal of Business and Management.

Marx, K., \& Fngels, F. (1932). Manifesto of the Communist Party. New York: International Publisher.

Maslow, A. (1956). Eupsychim Management: Homewood. Irwin.

News Naji. (2013 January 1). Retrieved from http://www.news.naji.com

Nigerian Muse. (2012, January 9). Retrieved from http://www.nigeriamuse.com

Oil and Gas online News. (2013, January 5). Retrieved from http://www.ppguideonline.com

Onyishi, A. O., \& Asogwa, M. N. (2009). Labour-Management Conflict in the Local Government System in Enugu State 1999-2007. University of Nigeria Journal of Political Economy, 3.

Otobo, D. (1987). Strikes and Lockouts in Nigeria: Some Theoretical Notes. The Nigerian Journal of Economic and Social Studies, 25(3), 301-318.

Poole, M. (2001). Industrial and Labour Relations. In P. Michael, \& W. Malcolm (Eds.), The IEBM of Human Resource Management. London: Thomson Learning.

Punch Newspaper. (2012, January 4).

Punch Newspaper. (2012, January 17).

Punch Newspaper. (2012, January 18).

Punch Newspaper. (2012, January 20).

Radin, B. A. (2007). The Instrument of Intergovernmental Management. In B. P. Guy, \& J. Pierre (Eds), The Handbook of Public Administration. London: Sage Publications Limited.

Robbin, S. P., \& Judge, T. A (2008). Organizational Behaviour (13th ed.). New Delhi, PHI Learning Private LTD.

Robbins, S. P. (1974). Managing Organizational Conflicts: A Non-Traditional Approach. Englewood Cliffs, N.J. Prentice Hall.

Simmel, G. (1955). Conflict and the Web of Group Affiliations. Glencoe IL, The Free Press.

Smith, K. A (2002). Conflict Management. Magraw-Hills, Best Series- Basic Engineering Series and Tools.

Sun Newspaper online. (2012, February 2 2). Retrieved from http://www.latestnigeriannews.com/thesun/nigeria-daily-sun-newspaper

Sun Newspaper online. (2012, June 14). $\quad$ Retrieved from http://www.latestnigeriannews.com/thesun/nigeria-daily-sun-newspaper

TELL Magazine. (2012, February 6). No. 5.

TELL Magazine. (2012, January 30). No. 4.

TELL Magazine. (2012, January 9). No. 1.

The Nigeria Voice. (2012, January 31).

ThisDay Newspaper. (2012, January 15). 
Transformation watch online. (2013, January 5). Retrieved from http://transformationwatch.com/henry-omoregie

Tribune Newspaper online. (2012, March http://www.latestnigeriannews/latest-news/tribune/nigeria-newspaper

Tribune Newspaper online. (2012, March $\mathrm{http}: / /$ www.latestnigeriannews/latest-news/tribune/nigeria-newspaper

12). $\quad$ Retrieved from

SAID. (2005). Conflict Management and Mitigation http://www.devex.com/projects/conflict-management-and-mitigation

Vanguard Newspaper online. (2012, August 14). Retrieved from http://www.latestnigeriannews.com/latest-new/vangard/nigeria-newspaper

Vanguard Newspaper online. (2012, December 12). Retrieved from http://www.latestnigeriannews.com/latest-new/vangard/nigeria-newspaper

Vanguard Newspaper online. (2013, August, 9). Retrieved from http://www.latestnigeriannews.com/latest-new/vangard/nigeria-newspaper

Vanguard Newspaper. (2012, August 14).

Vanguard Newspaper. (2012, January 12).

Vanguard Newspaper. (2012, January 19).

\section{Copyrights}

Copyright for this article is retained by the author(s), with first publication rights granted to the journal.

This is an open-access article distributed under the terms and conditions of the Creative Commons Attribution license (http://creativecommons.org/licenses/by/3.0/). 